\title{
Probabilistic Modeling of Oil Spills at the Exclusive Economic Zone of Cuba Using Petromar-3D Model
}

\author{
Alejandro Rodríguez ${ }^{1}$, Dayron Chang1, Amilcar E. Calzada1, Dayana Carracedo, \\ Dailín Reyes ${ }^{1}$, Alexander Lobaina ${ }^{2}$, Reinaldo Casals ${ }^{1}$, Jessica Hernández ${ }^{1}$, \\ Javier Cabrales ${ }^{1}$ \\ ${ }^{1}$ Institute of Meteorology of Cuba, Havana, Cuba \\ ${ }^{2}$ Meteorology Office of Cuban Company for Air Navigation (ECNA - AISMet), Havana, Cuba \\ Email: alejandro.rodriguez@insmet.cu
}

How to cite this paper: Rodríguez, A., Chang, D., Calzada, A. E., Carracedo, D., Reyes, D., Lobaina, A., Casals, R., Hernández, J., \& Cabrales, J. (2021). Probabilistic Modeling of Oil Spills at the Exclusive Economic Zone of Cuba Using Petromar-3D Model. Journal of Geoscience and Environment Protection, 9, 21-34.

https://doi.org/10.4236/gep.2021.96002

Received: December 9, 2020

Accepted: June 7, 2021

Published: June 10, 2021

Copyright $\odot 2021$ by author(s) and Scientific Research Publishing Inc. This work is licensed under the Creative Commons Attribution International License (CC BY 4.0).

http://creativecommons.org/licenses/by/4.0/

\begin{abstract}
This article shows the probabilistic modeling of hydrocarbon spills on the surface of the sea, using climatology data of oil spill trajectories yielded by applying the lagrangian model PETROMAR-3D. To achieve this goal, several computing and statistical tools were used to develop the probabilistic modeling solution based in the methodology of Guo. Solution was implemented using a databases approach and SQL language. A case study is presented which is based on a hypothetical spill in a location inside the Exclusive Economic Zone of Cuba. Important outputs and products of probabilistic modeling were obtained, which are very useful for decision-makers and operators in charge to face oil spill accidents and prepare contingency plans to minimize its effects. In order to study the relationship between the initial trajectory and the arrival of hydrocarbons spills to the coast, a new approach is introduced as an incoming perspective for modeling. It consists in storage in databases the direction of movement of the oil slick at the first 24 hours. The probabilistic modeling solution presented is of great importance for hazard studies of oil spills in Cuban coastal areas.
\end{abstract}

\section{Keywords}

Oil Spill Modeling, Petromar, Lagrangian Model, Probabilistic Modeling

\section{Introduction}

Oil spill probabilistic models are an important tool to analyze future possible scenarios that decision-makers and operational work groups could face, in order 
to fine-tuning contingency plans for accidents (Fingas, 2011). For this purpose, both continuous and homogeneous samples of meteorological and oceanographic variables are considered in normal conditions, or in the presence of extreme weather events such as cold fronts and tropical cyclones.

These models calculate the probability of pollutants arrival to the coast due to an oil spill. They have the capability to calculate the limit in distance and direction to which spills could fate from a given location. Thus, areas where there is high probability of impact by hydrocarbons are identified (West \& Solsberg, 1998).

Size-specific spills are considered in modeling and usually only surface advection is included in trajectory calculations. The intrusion of oil slicks in the coasts, beaches and fishing areas, as well as other important ecological and economic resources, can easily be included in these models (Amir-Heidari et al., 2019).

Currently, the probabilistic models run starting the climatology of hypothetical spill paths, from a geographical coordinate. Physical and chemical processes involved in weathering and blowout are included in the modeling (Spaulding, 2017). Once the multiple runs are done, the information of the trajectory of the oil slick for each scenario is collected.

The Marine Meteorology Center (CMM) of the Institute of Meteorology of Cuba (INSMET) has developed the lagrangian model PETROMAR-3D (Calzada et al., 2010; Calzada et al., 2015; Calzada et al., 2020), which forecasts the trajectory of the hydrocarbon at drift spilled at sea, and also, indicates the coastal areas that could be affected and the time of the damage. Likewise, it suggests to decision-makers the response techniques that should be used to mitigate the disaster, depending on the existing atmospheric and oceanographic conditions.

However, just a trajectory model is not enough to do hazard analysis in the coastal areas, in the presence of an oil spill event and neither provides the necessary information to design the contingency plans for possible disasters, during drilling and transportation of oil in the seas.

Given the exposure of ecosystems, economic sectors and coastal population settlements to oil disasters hazard, it is necessary not only to predict single trajectories of oil slicks but also to provide hazard maps with the probability for the occurrence of such events. This article aims to carry out the probabilistic modeling of oil slicks over the sea using a database design.

Following the Introduction, Section 2 describes the characteristics EEZ of Cuba in the Gulf of Mexico as a case study with the methodology, tools and equations used in the probabilistic calculus. In Section 3, the outputs of the probabilistic modeling are shown and each of them is discussed by comparing maps. In Section 4 , a new product is shown as a future perspective in the modeling. Finally, conclusions are presented in Section 5.

\section{Methods and Materials}

After a meticulous search for information about the state of the art on oil spill 
modeling, both native and international experiences were taken into account, and a combination of computational, meteorological and statistical tools was implemented for designing the probabilistic model of oil spills.

\subsection{Brief Oceanographic and Meteorological Characterization of the EEZ of Cuba in the Gulf of Mexico}

As a case study for the implementation of probabilistic modeling, the region of the Gulf of Mexico belonging to the EEZ of Cuba was chosen. This area constitutes a mega-basin of abundant oil that is also shared by the US and Mexico (Felipe, 2016). In addition, the dynamics of the hydrometeorological variables (which are used as input data to the PETROMAR-3D model) is very complex; and this directly affects the calculations of the processes of transport of the oil slicks. Therefore, it is convenient to know the characteristics of this area to understand the outputs of the model.

The EEZ region is extended from northwestern coast of the island of Cuba toward southeastern portion of the Gulf of Mexico. In the version of May 2009, the Official Gazette of the Republic of Cuba (Ministerio de Justicia, 2009), through the Decree Law 266, Article 1, defined the Exclusive Economic Zone of Cuba in the Gulf of Mexico as:

"The outer limit of the Exclusive Economic Zone of the Republic of Cuba in the Gulf of Mexico, which is defined by an arc of geodetic lines, whose points are located at a distance of 200 nautical miles measured from the closest point of the straight base lines system, from where the width of the Cuban Territorial Sea is measured" (Table 1).

In this region, there is the flow of the Loop Current, which joins the Yucatan and the Florida Currents in the eastern half of the gulf. Associated with the Florida Current and the anticyclonic turn of the Loop Current, and located at the western entrance to the Straits of Florida, a mesoscale anticyclonic vortex (known as CubAN) is developed along the northwestern coast of Cuba. The dynamics and interaction of current systems have been analyzed by authors in the region using satellite data, modeling and instrumental measurements. Two types of eddies have been characterized: a main anticyclonic cell, within the core of the Loop Current as an extension (type A) and an individual anticyclonic eddy, detaching from the core itself and displaced eastward along the northwestern $\mathrm{cu}-$ ban coast. (type B) (Kourafalou et al., 2017)

Table 1. Geographic coordinates depicting the Cuba's exclusive economic zone in the Gulf of Mexico.

\begin{tabular}{ccc}
\hline Points & Latitude & Longitude \\
\hline 1 & $24^{\circ} 56^{\prime} 28^{\prime \prime} .83$ & $-86^{\circ} 56^{\prime} 16^{\prime \prime} .69$ \\
2 & $25^{\circ} 03^{\prime} 29^{\prime \prime} .14$ & $-86^{\circ} 47^{\prime} 05^{\prime \prime} .90$ \\
3 & $25^{\circ} 07^{\prime} 52^{\prime \prime} .92$ & $-86^{\circ} 41^{\prime} 07^{\prime \prime} .08$ \\
4 & $25^{\circ} 12^{\prime} 25^{\prime \prime} .00$ & $-86^{\circ} 33^{\prime} 12^{\prime \prime} .00$
\end{tabular}


On the other hand, the usual wind regime in the area, as in the rest of the island, is basically determined by the influence of trade winds circulation with an average speed of $2.8 \mathrm{~m} / \mathrm{s}$ according to studies cited in more recent articles (Lecha et al., 1994; Mitrani et al., 2019). This normal regime is usually altered by tropical and extratropical extreme weather events, such as cold fronts, extratropical lows and tropical cyclones.

The maximum values of the sea surface temperature and the depth of the isothermal layer are of particular interest for analyzing hurricane intensification. A warm pool is located in this area, which propitiates the intensification of hurricanes (Mitrani, 2017).

Finally, in this area of the EEZ the Guanahacabibes peninsula is found at north in the western tip of the island of Cuba. There a wide insular shelf with reduced depth, shallow shore and a weak slope that favors the rise of the sea level. This is due to the persistence of the wind setup during hurricane surges and cold fronts. Therefore, coastal flooding is possible in presence of these events (Rodríguez-Pupo et al., 2020).

\subsection{Methodologies for Probabilistic Modeling}

Numerous methodologies have been established to do probabilistic studies of oil spills (Abascal et al., 2010; Alves et al., 2014; Guo et al., 2016). The methodology applied by Guo to the probabilistic modeling in the port of Dalian Bay, China was chosen and adapted to open sea conditions around northwestern coast of Cuba. This methodology is established as follows:

1) Spill size estimation, based on averaged historical data or the maximum probability, depending on the technological operation to be simulated;

2) Selecting the properties of the leaking oil (density, viscosity, surface tension, volatility, solubility, etc.);

3) Selecting the initial time of the spill, assuming that accidents occur in independent and time uniform manner, unless restricted conditions are stated;

4) Providing accurate atmospheric and oceanographic information from numerical models or historical records (currents, waves, and winds);

5) Simulating the processes of oil slick transport, recording relevant information (whether each grid is polluted or not, the earliest time the oil slick reaches each cell, the mean of the slick thickness in each cell, etc.);

6) Running numerous scenarios of oil spill events for obtaining statistical results under different conditions;

7) Completing statistical calculation of results from every scenario.

To implement this methodology, an adaptation was necessary (Figure 1). The first point in the methodology of Guo assumes that there are historical records of oil spills. In the present case, since there is no official spill record exiting in the area, it was convenient to initialize the amount of fuel discharged in 10,000 barrels into the PETROMAR-3D runs. Remaining points of the methodology were used as described. 


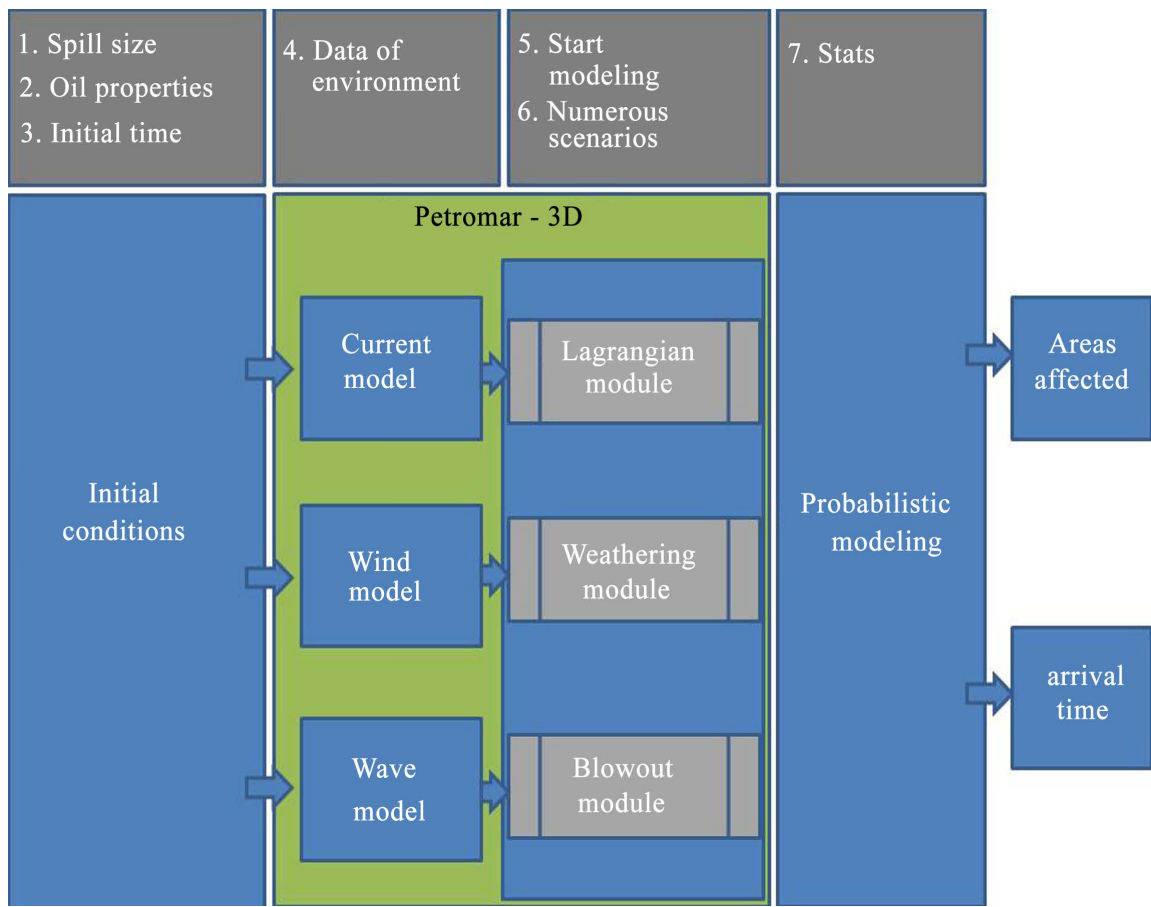

Figure 1. Diagram showing the steps of Guo's methodology at each moment of the modeling process.

In this way, the methodology was applied as follows: the initial conditions of the spill were established for probabilistic modeling in the coordinates $23.28^{\circ}$ north latitude and $85.18^{\circ}$ west longitude (located within the Cuba's EEZ of the Gulf of Mexico) with a duration of ten day. Each spill was considered as an instant spill of 20 API (heavy oil of $933.1 \mathrm{~kg} / \mathrm{m}^{3}$ ) and starting at 00:00 hour.

\subsection{Petromar-3D Model}

The main tool used in this work is the PETROMAR - 3D model (Calzada et al., 2020), a lagrangian scheme for computing oil spill trajectories, created at the Marine Meteorology Center from Institute of Meteorology. This model takes the numerical outputs from various atmospheric, hydrodynamic and wave models, as well as other input data for drift and weathering calculations. The data used in the creation of the scenarios to do this exercise, came from a time series of 7 years (between 2003 and 2009) of atmospheric and oceanographic models that are detailed below:

- CFS (Climatic Forecast System) by NCEP (Saha et al., 2010). This new version of the CFS model completes a 29-year period (1982-2011) for seasonal and sub-seasonal operational forecasting. It has a spatial resolution of $32 \mathrm{~km}$ (in tropical latitudes) and a temporal resolution of 1 hour.

- HYCOM (Hybrid Coordinate Ocean Model). Its horizontal regular grid presents an average space of $7 \mathrm{~km}$ and 32 vertical layers.

The website http://www.hycom.org/dataserver/ provides access to the global ocean prediction system outputs at near real time (Hycom, 2019). 
Several evaluations have been carried out with the PETROMAR-3D model. However, the model has not had a validation process due to limitations with the data. The comparison patterns, in most cases, have been the drifters owned by NOAA (Calzada et al., 2015: p. 8) obtained through the COAST-WATCH service (accessed until 2018 at the site:

https://cwcaribbean.aoml.noaa.gov/CURRENTS/index.html). The effectiveness of the calculations obtained has been acceptable (92.4\%), taking into account the complexity present in the dynamics of the marine flow in the inter-American sea (Calzada et al., 2015: p. 8).

In the proposed probabilistic modeling, the evaluation will be made by comparing the probabilistic fields yielded by the model and the contingency plans made for events that occur during the years of implementation.

\subsection{Computing Tools for Probabilistic Modeling}

For the probabilistic modeling, the PostgreSQL database engine (PostgreSQL, 2019) was used to store the climatology of hypothetical oil spills trajectories starting from an initial point, PgAdmin was used as PostgreSQL client (PgAdmin, 2019). Both tools can also run on Windows.

The necessary Python scripts to implement the probabilistic modeling were developed using Pycharm Community IDE (Pycharm, 2019). For designing the affected coastal sectors it was used the open source and multiplatform geographic information system QGIS (Qgis, 2019).

\subsection{Probability Calculations}

Oil spill probabilistic model outputs probability fields over a grid which specifies which areas could be affected by the spills (Guo et al., 2016). The cumulative probability $(\mathrm{CP})$ of pollution occurrence in each grid point is defined as

$$
\mathrm{CP}(x, y)=\frac{\mathrm{NC}(x, y)}{\mathrm{NS}},
$$

where $(x, y)$ are geographic coordinates of the point, NC is the number of times the point is affected by the pollutant (in a $\xi$ predefined neighborhood), during the simulation process and NS is the number of scenarios.

Transient probability (TP) is the probability for a cell of the grid of being affected by the oil slick at some point after the spill. It is calculated by

$$
\mathrm{TP}(x, y, t)=\frac{\mathrm{NP}(x, y, t)}{\mathrm{NS}} * 100,
$$

where NP is the number of times the point was covered by an oil slick at a t-time (Guo et al., 2016).

\section{Results and Discussion}

With the development of scripts programmed in Python 2.7 language, a series of operations of the Petromar-3D model were used. Among them, the transformation of geographical coordinates, verification of oil slick location on the coast, 
calculating the direction of the pollutants after 24 hours of the accident occurrence, and saving all the information in databases.

Probabilistic modeling is done by means of SQL language, which can be used depending on the computing tool chosen by the user. Python, QGis (or any other geographic information system), even the database itself; are examples of it. With the features offered by these technologies, modeling can be performed in a corporate network.

Another very advantageous feature of modeling by means of SQL language is its ability to retrieve the information from the database by a simple query at any time interval. These queries may be made seasonal, monthly, weekly, by specific areas, etc.

Figure 2 shows SQL queries made to the database, trough a Python script to calculate the probability of affected areas by pollutants, in case of an oil spill event for a given month, and the estimated time of arrival to the coast. In the particular case shown in (a), the $\mathrm{CP}$ is calculated for October, dividing the total number of repetitions for each affected point by the number of run scenarios, which is expressed in percent. In the case (b) a similar calculation is made for points located in the coastal sector for January.

In this way, the database receive the information calculated by PETROMAR-3D model as text files and then, by means of the SQL language, modeling results are managed, consulted and used in the maps, trough Python scripts or QGIS.

As a result of that, different maps are generated for a wide variety of analyzes. The authors have adjusted the outputs to demands of the users, in order to provide simple and flexible maps.

\subsection{Areas Potentially Affected by Spills}

In Figure 3 are identified the most likely areas to be affected by an oil spill, if it occurs in January, May, August or October (starting at the point indicated on the map). The different probability ranges for the polluted areas are shown using a chromatic scale.

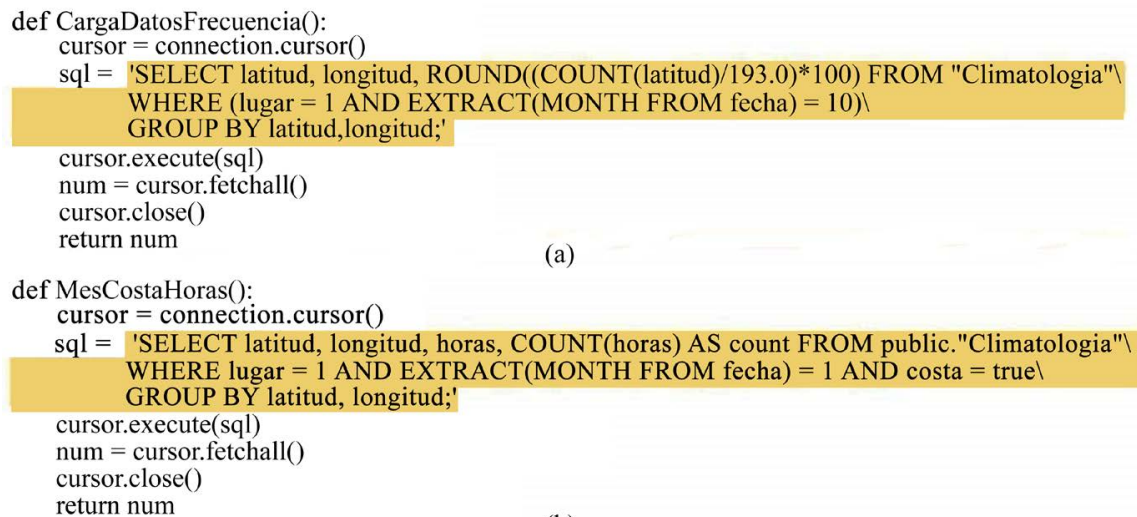

def MesCostaHoras(): cursor = connection.cursor()

sql = 'SELECT latitud, longitud, horas, COUNT(horas) AS count FROM public."Climatologia" WHERE lugar = 1 AND EXTRACT(MONTH FROM fecha) $=1$ AND costa $=$ truel GROUP BY latitud, longitud;'

Figure 2. Probability calculation using SQL language. (a) Probability of impact by pollution for a given month and (b) Required time for the pollutant reaches the coast. 


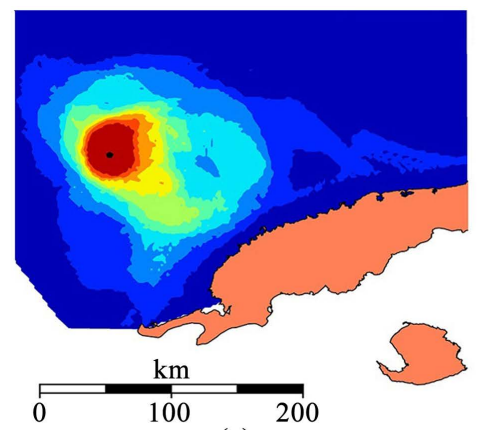

(a)

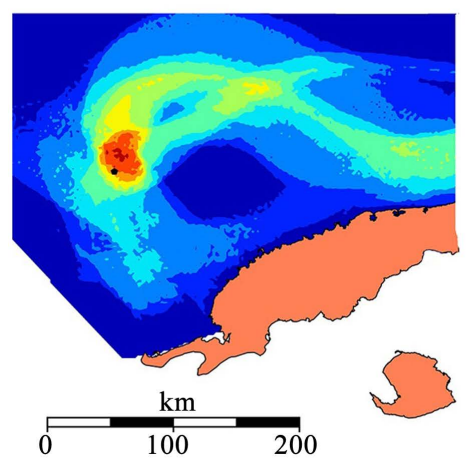

(c)

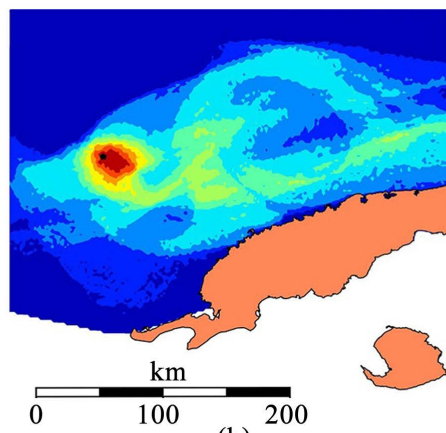

(b)

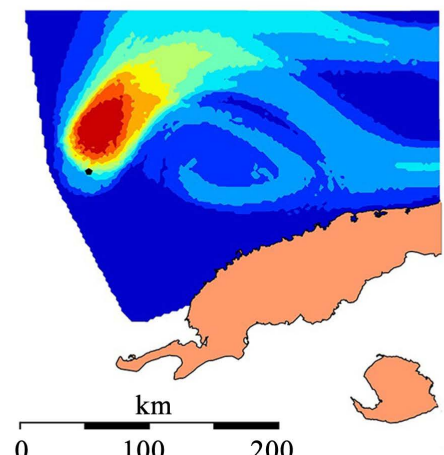

(d)

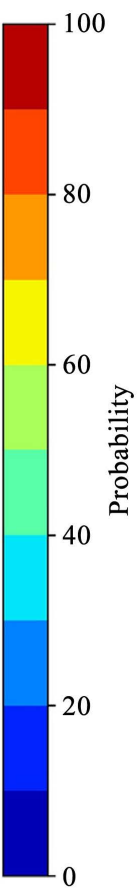

Figure 3. Areas potentially affected: (a) January; (b) May; (c) August and (d) October, (applying CP calculation).

It is noticeable that, in a high percentage chances, the initial course of the drift occurs northeastward in cases (a), (c) and (d). Areas with a probability greater than 30 percent are concentrated in a neighborhood near the spill site. This characteristic suggests that the vortex system of the area plays a determining role in the drift, keeping the pollutant trapped. It is convenient knowing this fact, because decision makers would have time to implement protocols minimizing damage.

Figure 3(d) illustrates that transport is stronger since early days of October, but (despite the influence of vortex elements) the pollutant does not reach the cuban coasts and instead of that enters to the Straits of Florida in most cases. When the images of the Figure 3 are compared, a difference in the probability distribution can be noticed, depending on the characteristics of oceanic and atmospheric flows for each season in the year.

For decision makers, it is of a great importance to know the location of the higher probability area affected by the oil spilled. This is a classic product and highly demanded of the majority of up to dated models.

\subsection{Areas Potentially Affected by Hours}

Figure 4 shows the resulting maps from the transient probability calculation for 12 hours after the spill occurrence on analyzed months. At the early hours of the spill, the oil slick movement is governed by the physical process of spreading. In this process the pollution is expanded, conditioning other transformation 


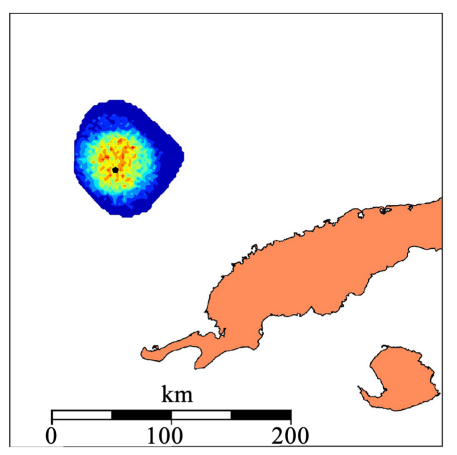

(a)

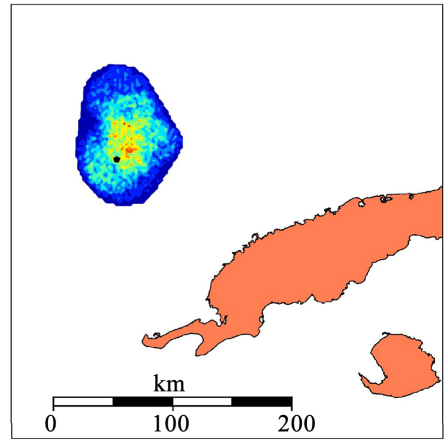

(c)

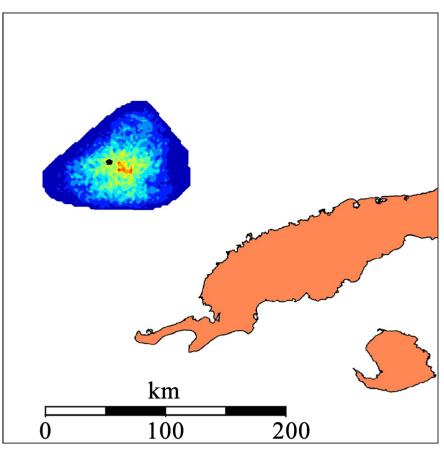

(b)

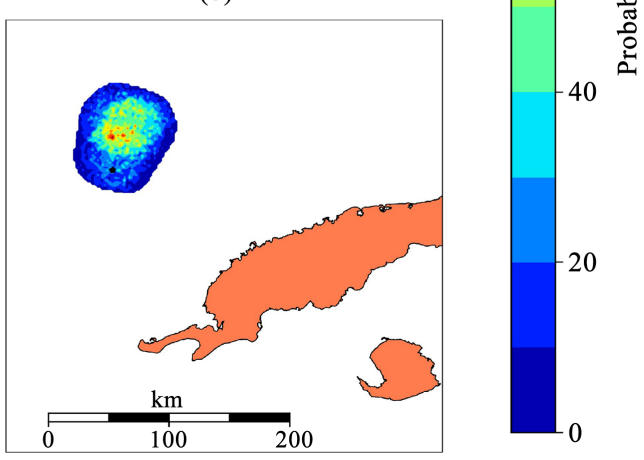

(d)

Figure 4. Potentially affected areas at noon (12:00 hours): (a) January; (b) May; (c) August and (d) October. Map generated applying TP calculation.

processes on the slick (Palacios Pérez et al., 1987; Salas de León, 1987), with an increasing of mass transfer by evaporation and dissolution.

In cases a, $\mathrm{c}$ and $\mathrm{d}$ of Figure 4, it can be seen that high probability values are located toward north and northeast. However, on October (case b), the slick movement tends to east-southeast.

\subsection{Oil Slick Arrival Time to the Coast}

Another useful aspect for decision makers that reinforces response plans, is the information about the time elapsed until any coastal sector be affected for the first time, which gives to the response groups a timely reaction to deal with the spill in a safe and efficient mode. Thus, the coastal sector length and arrival time are incorporated as available information for preparing the aforementioned plans.

In Figure 5 time intervals can be distinguished in ranges from 87 to 239 hours. In each month the details are well defined for each case, but in order to favor the comparisons were considered coastline lengths expressed in kilometers where the oil spill arrive before 163 hours (six and a half days).

For case a (Figure 5), it is shown the arrival time to the coast for the northwestern sector of Cuba, for January. This is the month with the lowest time values, being evidenced that in the neighborhood of longitude $83.6^{\circ} \mathrm{W}$ is produced the widest dispersion for the majority of the modeled slicks. In coastal sectors located on both sides, the pollutant appears after 201 hours (red color). 


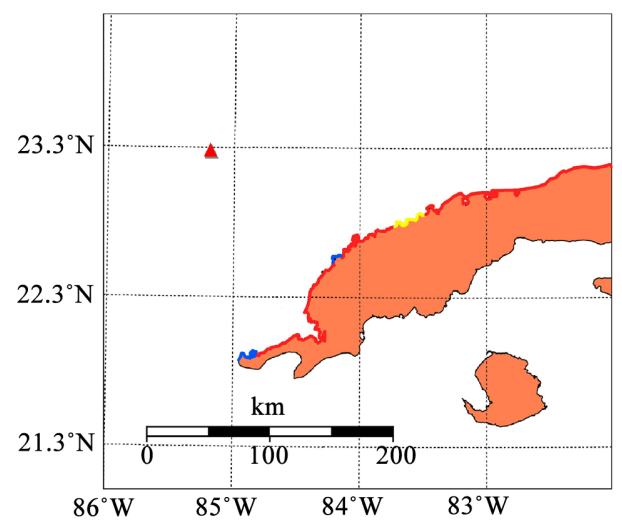

(a)

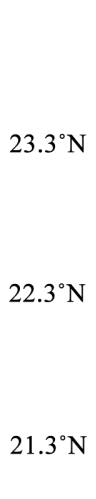

$1.3^{\circ} \mathrm{N} 21.3^{\circ} \mathrm{N}$

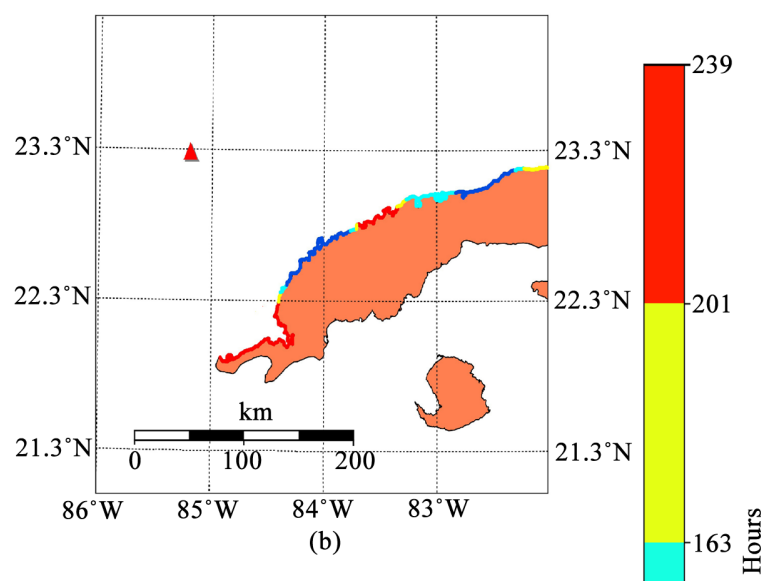

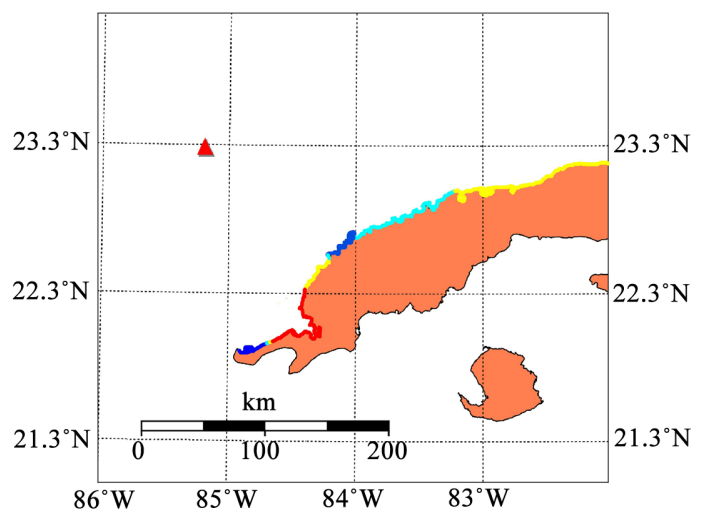

(c)

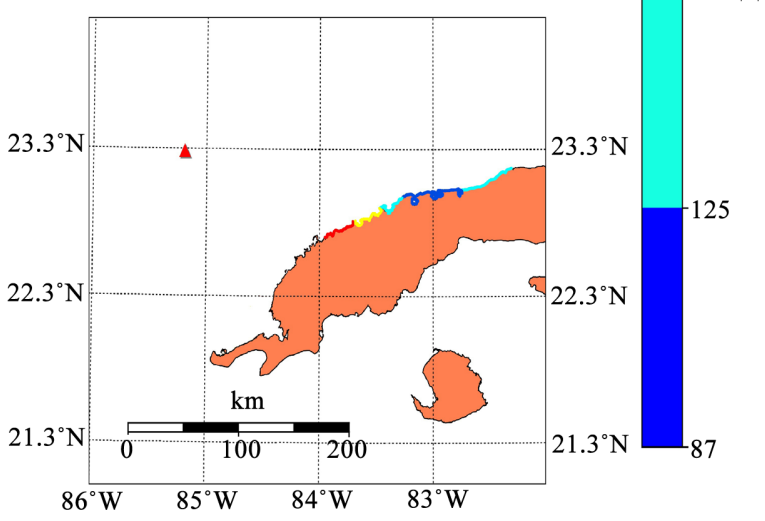

(d)

Figure 5. Oil slick arrival time to the coast (in hours): (a) January; (b) May; (c) August and d) October.

It is also revealed that approximately $594 \mathrm{~km}$ of coastline are affected, but only in $8 \%$ of it $(46.7 \mathrm{~km})$ the pollutant arrives before 163 hours.

Case b represents the values for May, with an impact of $594 \mathrm{~km}$ of coastline polluted. There is a noticeable trend to the occurrence of the pollutant dispersion in two coastal sectors in the neighborhood of longitudes $82.6^{\circ} \mathrm{W}$ and $84.1^{\circ} \mathrm{W}$. It is perceived also how there is a progressive distribution of the arrival hours variable on both boundaries of the indicated locations, according to the color ranges of the map. In a later analysis using the database, it could be distinguished to which meteorological and/or oceanographic conditions correspond the two represented areas.

Considering the oil spills hazard that could take place this month, in about $305 \mathrm{~km}$ of the total 594 (51\%) the time arrival is less than 6.5 days.

For August (case c) there are also two zones with a trend to slick dispersion from the longitudes $84.1^{\circ} \mathrm{W}$ and $84.8^{\circ} \mathrm{W}$. The first zone presents a progressive distribution of the different ranges on each side. The second one shows a distribution only to one side, due to being very close to the western end.

Taking into consideration the oil spill hazard at this month, in about $233 \mathrm{~km}$ of coast length (39\%) the arrival time is less than 6.5 days. Like in previous case, oil arrives at all points of the coast at some time.

October (case d) shows changes regarding to the previous cases, as it has only 
one zone where slicks are dispersed in the neighborhood of longitude $83^{\circ} \mathrm{W}$. As it is shown, there is a certain drift preference westward, due to the evident influence of the cuban countercurrent flowing from the Hicacos peninsula towards the Cuba's western tip (Arriaza, 2018).

Considering the oil spill hazard in October month, in about $190.4 \mathrm{~km}$ of coast length, (32\%) the oil arrives before 6.5 days to the coast. However, there are places where the pollutant never arrives to the coast and the pollution impact occur on $269 \mathrm{~km}$ of coastline (45\% of total coastline), which makes this month one of the least hazardous when an oil spill take place from the indicated initial point.

\section{Future Perspectives of the Probabilistic Model}

Developed database has an unprecedented characteristic in the oil spill probabilistic modeling for an initial point: an "apparent" relationship has been observed by the authors between oil slick motion direction in the first 24 hours and the affected coastal sector, if the arrival occurs (Rodríguez-Pupo et al., 2020).

This fact makes possible to speculate about the events that could occur at the end of the scenario with just a few hours of execution, which could lead to successful decisions in advance. Nevertheless, in order to fulfill these considerations, a sufficiently large data population must be available to provide reliability to this statement.

For such cases, the proposed procedure should be supplemented with absolute error calculations, in order to bring reliable information to users and decide whether to include it or not on official documents.

As an example, Figure 6 shows the coastal sectors affected in relation to the initial course of the slick.

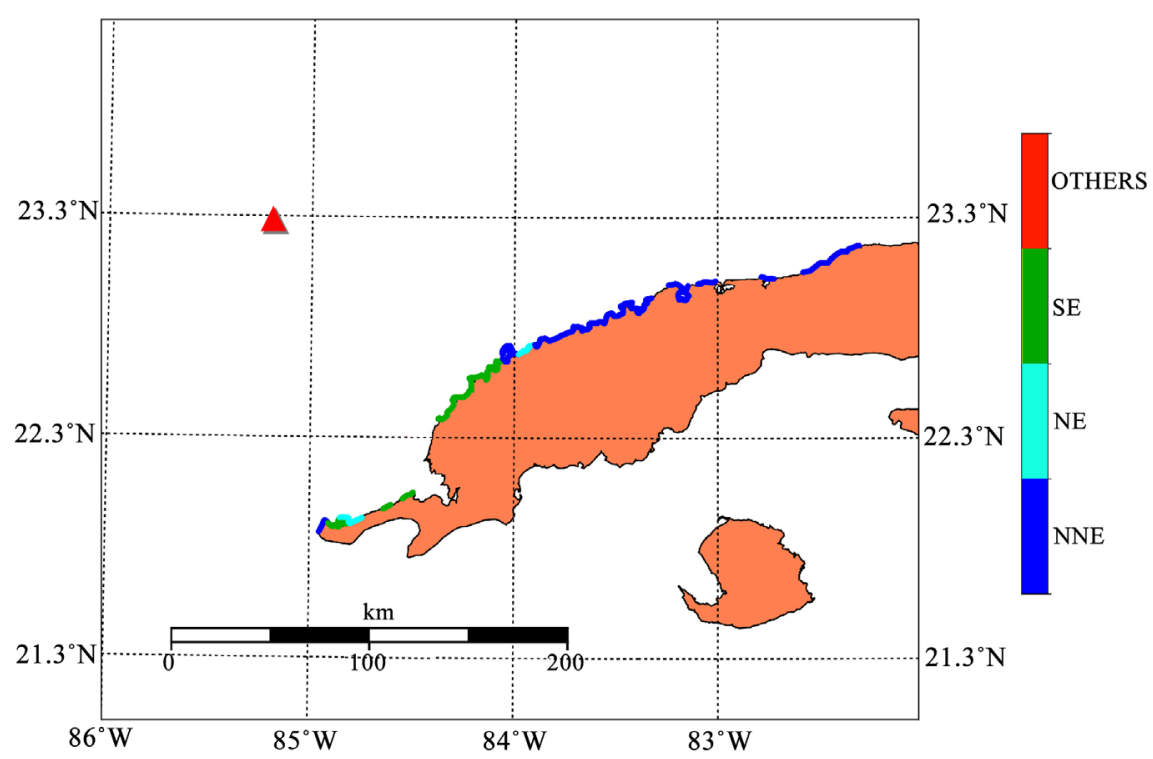

Figure 6. Oil slick arrival to coastal sectors regarding its course at the first 24 hours. 


\section{Conclusion}

1) New functions have been incorporated into PETROMAR-3D model, creating the capabilities to obtain the oil spill trajectories climatology and carrying out probabilistic studies on seas surrounding Cuba.

2) With the calculation of probability by means of the SQL language, the integration and interaction between different computer technologies is facilitated, which allows to compute the probability of affected areas by an oil spill originated at a point on the sea.

3) By means of a database, the probabilistic modeling was carried out, having the capability of preserving and managing all the information, which constitute a reliable and sustainable technological solution over time.

4) Analyzing the northwestern region of the Exclusive Economic Zone of $\mathrm{Cu}$ ba as a case study, a group of outputs from probabilistic modeling were obtained, which helps the decision-makers in the elaboration of contingency plans to confront oil spills on the sea.

\section{Acknowledgements}

This manuscript has been published thanks to the sponsorship of Mr. Luis E. Toro, a friend of the authors.

\section{Conflicts of Interest}

The authors declare no conflicts of interest regarding the publication of this paper.

\section{References}

Abascal, A. J., Castanedo, S., Medina, R., \& Liste, M. (2010). Analysis of the Reliability of a Statistical Oil Spill Response Model. Marine Pollution Bulletin, 60, 2099-2110. https://doi.org/10.1016/j.marpolbul.2010.07.008

Alves, T. M., Kokinou, E., \& Zodiatis, G. (2014). A Three-Step Model to Assess Shoreline and Offshore Susceptibility to Oil Spills: The South Aegean (Crete) as an Analogue for Confined Marine Basins. Marine Pollution Bulletin, 86, 443-457.

https://doi.org/10.1016/j.marpolbul.2014.06.034

Amir-Heidari, P., Arneborg, L., Lindgren, J. F., Lindhe, A., Rosén, L., Raie, M., Axell, L., \& Hassellöv, I.-M. (2019). A State-of-the-Art Model for Spatial and Stochastic Oil Spill Risk Assessment: A Case Study of Oil Spill from a Shipwreck. Environment International, 126, 309-320. https://doi.org/10.1016/j.envint.2019.02.037

Arriaza, L. (2018). Conectividad dinámica en las aguas oceánicas alrededor de Cuba: La contracorriente cubana entre Cabo de San Antonio y península de hicacos. MarCuba 2018, La Habana. http://www.congresomarcuba.com/programa-cientifico.pdf

Calzada, A. E., Delgado, I., Ramos, C., Pérez, F., Reyes, D., Carracedo, D., Rodríguez, A., Chang, D., Cabrales, J., \& Lobaina, A. (2020). Lagrangian Model PETROMAR-3D to Describe Complex Processes in Marine Oil Spills. Open Journal of Marine Science, 11, 17-40. https://doi.org/10.4236/ojms.2021.111002

Calzada, A. E., Fernández, K., Guilarte, Y., Rodríguez, R., Bezanilla, A., Casals, R., Amboaje, Y., \& Ramos, A. (2010). Oil Slick's Trajectory and Fate Forecast on the Sea at 
Cuba's Northwest Zone by Means of Petromar Software. https://www.oceandocs.org/handle/1834/3560

Calzada, A., Perez, F., Reyes, D., \& Casals, R. (2015). Modelación de los derrames de petróleo mediante el empleo de PETROMAR. Revista Cubana de Meteorologia, 21, 57-69.

Felipe, K. (2016). La ruta del petróleo en Cuba (Primera Parte). Granma.cu. http://www.granma.cu/cuba/2016-09-30/la-ruta-del-petroleo-en-cuba-primera-parte-3 0-09-2016-13-09-41

Fingas, M. (2011). Introduction to Oil Spill Contingency Planning and Response Initiation. In Oil Spill Science and Technology (pp. 1027-1031). Elsevier. https://doi.org/10.1016/B978-1-85617-943-0.10028-0

Guo, W., Wu, G., Jiang, M., Xu, T., Yang, Z., Xie, M., \& Chen, X. (2016). A Modified Probabilistic Oil Spill Model and Its Application to the Dalian New Port Accident. Ocean Engineering, 121, 291-300. https://doi.org/10.1016/j.oceaneng.2016.05.054

Hycom (2019). Data Server. https://www.hycom.org/dataserver

Kourafalou, V., Androulidakis, Y., Hénaff, M. L., \& Kang, H. (2017). The Dynamics of Cuba Anticyclones (CubANs) and Interaction with the Loop Current/Florida Current System. Journal of Geophysical Research: Oceans, 122, 7897-7923. https://doi.org/10.1002/2017JC012928

Lecha, L., Paz, L., \& Lapinel, B. (1994). El clima de Cuba. Editorial Academia.

Ministerio de Justicia (2009). Decreto-ley no. 266 del limite exterior de la zona economica exclusiva de la republica de cuba en el golfo de mexico. Gaceta Oficial de la Republica de Cuba. http://extwprlegs1.fao.org/docs/pdf/cub91245.pdf

Mitrani, I. (2017). Meteorologia Marina. CITMATEL.

Mitrani, I., Perez, A., Cabrales, J., Povea, Y., Hernández, M., \& Diaz, O. O. (2019). Coastal Flood Forecast in Cuba, Due to Hurricanes, Using a Combination of Numerical Models. Revista Cubana de Meteorología, 25, 18.

Palacios Pérez, F., Viamontes Iglesias, L., \& Contaminación, I. D. (1987). Modelos para describir el comportamiento físico de derrames de petróleo en la zona de Marbella-Bahía de Cárdenas. En Modelos para describir el comportamiento físico de derrames de petróleo en la zona de Marbella-Bahía de Cárdenas. CIMAB.

PgAdmin (2019).pgAdmin-PostgreSQL Tools. https://www.pgadmin.org

PostgreSQL (2019). PostgreSQL: The World's Most Advanced Open Source Database. https://www.postgresql.org

Pycharm (2019). Descargar PyCharm: El IDE de Python para desarrolladores profesionales, por JetBrains. JetBrains. https://www.jetbrains.com/pycharm/download

Qgis (2019). Welcome to the QGIS Project! https://qgis.org/en/site

Rodríguez-Pupo, A., Calzada-Estrada, A. E., Lobaina-LaÓ, A., Carracedo-Hidalgo, D., \& Pérez-Perdomo, D. (2020). Resulta imprescindible la modelación probabilística de derrames de petróleo en la Zona Económica Exclusiva de Cuba? Revista Cubana de Meteorología, 26, Article 3. http://rcm.insmet.cu/index.php/rcm/article/view/521

Saha, S., Moorthi, S., Pan, H.-L., Wu, X., Wang, J., Nadiga, S., Tripp, P., Kistler, R., Woollen, J., Behringer, D., Liu, H., Stokes, D., Grumbine, R., Gayno, G., Wang, J., Hou, Y.-T., Chuang, H., Juang, H.-M. H., Sela, J., Goldberg, M. et al. (2010). The NCEP Climate Forecast System Reanalysis. Bulletin of the American Meteorological Society, 91, 1015-1058. https://doi.org/10.1175/2010BAMS3001.1

Salas de León, D. A. (1987). Modelo Numérico para la predicción del transporte y la dispersión de petróleo en el océano (Jornada de Estudio en Oceanología). CONACYT. 
Spaulding, M. L. (2017). State of the Art Review and Future Directions in Oil Spill Modeling. Marine Pollution Bulletin, 115, 7-19.

https://doi.org/10.1016/j.marpolbul.2017.01.001

West, M., \& Solsberg, L. (1998). Modelado de Trayectorias de Derrames de Hidrocarburos (Informe Ambiental No. 4). ARPEL. 